\title{
Isolation and characterization of class I MHC genes in the giant panda (Ailuropoda melanoleuca)
}

\author{
ZHU Ying, SUN DanDan, GE YunFa, YU Bin, CHEN YiYan \& WAN QiuHong* \\ The Key Laboratory of Conservation Biology for Endangered Wildlife of the Ministry of Education, State Conservation Center for Gene \\ Resources of Endangered Wildlife, College of Life Sciences, Zhejiang University, Hangzhou 310058, China
}

Received May 6, 2012; accepted October 8, 2012; published online November 23, 2012

\begin{abstract}
Artificial breeding is an important project to protect, recover and reintroduce endangered species. Knowledge of the population's genetic diversity at functional loci is important for the establishment of effective captive breeding programs. The major histocompatibility complex (MHC) genes are ideal candidate genetic markers to inform planned breeding, due to their high levels of polymorphism and importance in the main immune coding region of the vertebrate genome. In this study, we constructed BAC-based contigs and isolated six functional MHC class I genes from the giant panda (Ailuropoda melanoleuca), which we designated Aime-C, Aime-F, Aime-I, Aime-K, Aime-L and Aime-1906. Analyses of the tissue expression patterns and full-length cDNA sequences of these class I genes revealed that Aime-C, -F, -I and -L could be considered classical class I loci, due to their extensive expression patterns and normal exonic structures. In contrast, Aime-K and -1906 appeared to be nonclassical genes based on their tissue-specific expression patterns and the presence of an abnormal exon 7 in both genes. We established techniques for genotyping exons 2 and 3 of the classical loci using locus-specific single strand conformation polymorphism (SSCP) and sequence analysis. In the Chengdu captive population, we identified one monomorphic locus (Aime-F) and three polymorphic loci with different numbers of alleles (4/4/4 exon 2 alleles at Aime-C/I/L and 6/5/5 exon 3 alleles at Aime-C/I/L). The distributions of the Aime-C, -I and -L alleles among members of different families were in good agreement with the known pedigree relationships, suggesting that the genotyping results are reliable. Therefore, the MHC-I genotyping techniques established in this study may provide a powerful tool for the future design of scientific breeding or release/reintroduction programs.
\end{abstract}

giant panda, MHC class I, isolation, locus-specific genotyping

Citation: Zhu Y, Sun D D, Ge Y F, et al. Isolation and characterization of class I MHC genes in the giant panda (Ailuropoda melanoleuca). Chin Sci Bull, 2013, 58: 2140-2147, doi: 10.1007/s11434-012-5582-4

Many animal species are under threat due to human activities and habitat fragmentation, and effective management plans are needed to prevent the extinction of endangered or threatened species. Such plans may include captive breeding programs, which are widely used for the recovery and reintroduction of endangered species [1,2]. The main goal of these breeding programs is the maintenance of a stable, self-sustaining population that retains genetic diversity and experiences limited inbreeding $[3,4]$.

To establish an effective breeding program, it is important to first learn about the genetic diversity present in

*Corresponding author (email: qiuhongwan@zju.edu.cn) current populations [5]. Genetic analysis based on neutral markers, such as microsatellites, mitochondrial markers and single nucleotide polymorphisms, are widely used for such work [6]. These markers are useful for analyzing dispersal patterns and population histories, but are not effective for assessing the ability to adapt to environmental changes [6]. In order to assess such changes, we also need to investigate genetic diversity at functional loci such as the major histocompatibility complex (MHC) genes [7].

The MHC genes are ideal candidates for this work, due to their high polymorphism and importance in the main immune coding region of the vertebrate genome [8]. The MHC molecules can be classified into two groups: class I 
molecules, which are mainly associated with intracellular pathogens; and class II molecules, which are responsible for the presentation of extracellular pathogens [9]. The typical MHC class I molecule consists of an $\alpha$ chain and a $\beta 2$-microglobulin. The $\alpha$ chain includes three extracellular domains ( $\alpha 1, \alpha 2$ and $\alpha 3)$, a transmembrane portion (TM) and a cytoplasmic domain (Cyd-tail) [9]. The MHC genes can be further divided into classical (class Ia) and nonclassical (class $\mathrm{Ib}$ ) genes based on their polymorphisms, expression levels and functions [10].

The class Ib genes tend to be less polymorphic, show narrower ranges of tissue expression and have shorter cytoplasmic domains than the class Ia genes $[11,12]$. class Ib molecules have a range of functions [11], while class Ia molecules present endogenous peptides to CD8+ cells [13]. When "MHC-antigen complex" are formed and presented to the surface of the cell, $\mathrm{T}$ cell can be activated to remove pathogens and parasites [14].

High level of MHC polymorphism at MHC loci is maintained by coevolution of host with their parasites and pathogens [15]. Loss of alleles at MHC genes due to inbreeding depression, is thought to decrease the ability of populations to respond to pathogen $[7,14,16]$. Therefore, genetic variation at MHC loci is essential for captive breeding programs of endangered species.

The giant panda (Ailuropoda melanoleuca) is an endangered species endemic to China. To ensure the survival of this species, a captive breeding program was initiated in the 1980s [17]; at present, the captive populations include 328 individuals worldwide [18]. Some MHC studies have already been conducted on this rare species: MHC class II genes have been isolated [19-22] and locus-specific MHC genotyping techniques have been established [20,21]. However, only three class I MHC genes (Aime-128, Aime-152 and Aime-1906) have been isolated to date, and locus-specific class I MHC genotyping could not be performed due to problems with cross-locus amplification [23]. The isolation of the remaining class I MHC genes is an essential next step if we wish to accurately genotype the extremely similar functional MHC class I loci of the giant panda.

In the present work, we constructed BAC-based contig maps containing the MHC class I genes of the giant panda, and sequenced these contigs to resolve the classical and nonclassical class I genes. For each classical MHC class I gene, we developed locus-specific genotyping techniques for exons 2 and 3 . We validated the reliability of these techniques in a captive population and then used them to investigate the genetic diversity of this population.

\section{Materials and methods}

\subsection{Sampling and DNA extraction}

Blood and tissue samples were collected from 26 giant pandas with clear pedigree information [24] from the
Chengdu Giant Panda Breeding Research Base (Chengdu). Blood samples were obtained during routine medical examinations and stored in liquid nitrogen. Liver and brain tissues were obtained from dead captive pandas. Genomic DNA was extracted from the blood and tissue samples using standard phenol-chloroform methods [25].

\subsection{Construction of a BAC-based contig map of the MHC class I genes}

Two pairs of universal primer (C1E2F3/R1, C1E3F1/R1; Table 1) were designed based on the previously determined giant panda class I cDNA sequences (EU162658, EU162659, EU162660) and class I gene sequences from other carnivores (dog: NM_001014767, NM_001014378, NM_001014379; cheetah: U07665, U07666; cat: U07667, U07668, U07669, U07670, U07672, U07673, U07674; ocelot: U07675, U07676, U07677, U07678). The universal primers were used to screen BAC pools, and the MHC class I gene-containing BACs were identified with 4D-PCR and sequencing, as previously described [26]. All of the confirmed-positive BACs were subjected to commercial end-sequencing (Majorbio, Shanghai), the obtained end sequences were repeatmasked, and non-repeat ends were identified (http://www. repeatmasker.org). End-primers were designed and used to build BAC-based overlapping clusters [26], and the BACs showing minimum tiling paths in the overlapping cluster were subjected to commercial BAC sequencing (Majorbio). The results were used to construct a physical map and resolve the MHC class I gene-enriched contigs. Putative functional MHC class I genes were obtained from the contigs using GENESCAN (http://genes.mit.edu/GENSCAN).

\subsection{Expression patterns and full-length cDNA amplification of Aime-MHC class I genes}

Over the past decade, we obtained three types of fresh samples from three different captive individuals: blood from Chenggong (studbook No. 522; living), which was obtained during a routine medical examination; liver from Jiaozizhizi (No. 577; death in 2003); and brain from Eryatouzhizi (No. 599; death in 2003). Total RNA was extracted from these tissues using the TRIzol Total RNA Isolation Kit (Invitrogen), mRNA was purified with an Oligotex mRNA SpinColumn Kit (Qiagen), and full-length cDNA was generated using a SMART ${ }^{\mathrm{TM}}$ PCR cDNA Synthesis Kit (Clontech). Based on the coding sequences of the Aime-MHC class I genes predicted from the contigs using GENESCAN, we designed locus-specific primers (Table 1) and used them to detect expression in the different tissues. We then formulated locus-specific primer pairs for all of the expressed loci (Table 1; 5'UTR-exon 3 and exon 2-3'UTR) and used them to isolate the full-length cDNA sequences of the new AimeMHC class I genes (i.e. excluding the known genes, Aime128, -152 and -1906) [23]. 
Table 1 The primers used to isolate Aime-MHC class I genes ${ }^{\text {a) }}$

\begin{tabular}{|c|c|c|c|c|c|}
\hline Application & Primer nan & & Primer sequence $\left(5^{\prime} \rightarrow 3^{\prime}\right)$ & Size (bp) & $T_{\mathrm{a}}\left({ }^{\circ} \mathrm{C}\right)$ \\
\hline \multirow{4}{*}{ BAC pool screening } & C1E2- & F3 & GTGGACGACACGCAGTTCG & 190 & 62.0 \\
\hline & & $\mathrm{R} 1$ & CGGCCTCGCTCTGGTTGTAGTAGC & & \\
\hline & C1E3- & F1 & GCGCGGATTACATCGCCCTGAAC & 186 & 63.0 \\
\hline & & R1 & CGCGCTGCAGCGTCTCCTTCC & & \\
\hline \multirow{16}{*}{ End location } & $1611 \mathrm{G} 3-\mathrm{T} 7$ & $\mathrm{~F}$ & CTGCACCCCGCCCTCTA & 257 & 55.5 \\
\hline & & $\mathrm{R}$ & TCCCCCTGCCTGTGTTCC & & \\
\hline & 1611G3-RP2 & $\mathrm{F}$ & CACCCCTGCTGCCTTTCTCCTC & 233 & 59.2 \\
\hline & & $\mathrm{R}$ & TCTCCCGCCCTTAGTTCCAGTGAT & & \\
\hline & 1470D3-T7 & $\mathrm{F}$ & AGGCGCTGAAGAAATAAAAACTA & 338 & 53.1 \\
\hline & & $\mathrm{R}$ & CTTCTCCTGCCCCGCTGACTCCA & & \\
\hline & $1470 \mathrm{E} 1-\mathrm{T} 7$ & $\mathrm{~F}$ & TGCCGGCACCCATAGTAG & 385 & 56.0 \\
\hline & & $\mathrm{R}$ & GGCCATTTTCCCTCATTTC & & \\
\hline & 1470E1-RP2 & $\mathrm{F}$ & ATATCCCCAGGTGTAGAGTGTGAC & 280 & 55.5 \\
\hline & & $\mathrm{R}$ & AGGGGGAGTGGGAGAGGGAGAA & & \\
\hline & 1470E3-RP2 & $\mathrm{F}$ & CCCCCTCGCTTGGCATACTTCTGT & 339 & 60.5 \\
\hline & & $\mathrm{R}$ & AGCGGGTGTTGGCGGGTGTC & & \\
\hline & 897E9-T7 & $\mathrm{F}$ & GGGGCAGAAGCAAAGGAAGACA & 351 & 59.5 \\
\hline & & $\mathrm{R}$ & AGGCCGGGCTCAGGGTAAG & & \\
\hline & 897E9-RP2 & $\mathrm{F}$ & CGGCAGTAAGACAGGAAAGGAAC & 401 & 58.0 \\
\hline & & $\mathrm{R}$ & GTAACCCCGGGGCTCAGTCA & & \\
\hline \multirow{12}{*}{ Expression detection } & Aime-C- & $\mathrm{Fe}$ & GGACCGGGAGACGCGGATCAT & 876 & 60.5 \\
\hline & & $\mathrm{Ru}$ & TGCATCACTCAGTCCCCATG & & \\
\hline & Aime-F-(i.e. 152) & $\mathrm{cF}$ & GACCGGGAGACGCGGAAT & 815 & 61.5 \\
\hline & & $\mathrm{cR}$ & TCCCCACAAGGCAGCTCA & & \\
\hline & Aime-I-(i.e. 128) & $\mathrm{cF}$ & CCGAGTGGACTTGCAGACCGCC & 832 & 59.5 \\
\hline & & $\mathrm{cR}$ & CATCACTCAGTCCCCACG & & \\
\hline & Aime-K- & $\mathrm{Fe}$ & GAGGCCGGCTCTCACACTATG & 836 & 60.0 \\
\hline & & $\mathrm{Ru}$ & AAGAGAACTCAGGGGTTGTTGATG & & \\
\hline & Aime-L- & $\mathrm{Fe}$ & GCTCTCACACCATCCAGGA & 784 & 62.0 \\
\hline & & $\mathrm{Ru}$ & CATCACTCAGTCCCCACG & & \\
\hline & Aime-1906- & $\mathrm{cF}$ & GGAAGGGTCTCACACCTC & 849 & 54.5 \\
\hline & & $\mathrm{cR}$ & TTATGCTAATAGGAACATATA & & \\
\hline \multirow{12}{*}{$\begin{array}{l}\text { Isolation of the full-length } \\
\text { cDNA sequence }\end{array}$} & Aime-C- & $\mathrm{Fu}$ & CCCGCCAGTGGACCACTGTC & 428 & 61.5 \\
\hline & & $\operatorname{Re}$ & CAGCCGTACATCCACTGGTA & & \\
\hline & & $\mathrm{Fe}$ & - & 876 & 60.5 \\
\hline & & $\mathrm{Ru}$ & - & & \\
\hline & Aime-K- & $\mathrm{Fu}$ & TCTCCCCAGAACCTGGAG & 572 & 59.0 \\
\hline & & $\operatorname{Re}$ & TCCAGGTAGTTCCTGAGG & & \\
\hline & & $\mathrm{Fe}$ & - & 784 & 62.0 \\
\hline & & $\mathrm{Ru}$ & - & & \\
\hline & Aime-L- & $\mathrm{Fu}$ & CACGGTTTCGGGTTATAAG & 455 & 59.5 \\
\hline & & $\operatorname{Re}$ & AGGTCACAGCCGTGCATCTC & & \\
\hline & & $\mathrm{Fe}$ & - & 784 & 62.0 \\
\hline & & $\mathrm{Ru}$ & - & & \\
\hline
\end{tabular}




\subsection{Locus-specific amplification of the classical Aime- MHC class I loci}

For the classical Aime-MHC class I genes, we analyzed exons 2 and 3, which encode the highly variable $\alpha 1$ and $\alpha 2$ domains of the class I proteins. Given the highly similar intronic sequences adjacent to exons 2 and 3 of the classical genes, we used a nested-PCR genotyping technique (Table 2): the first round consisted of a locus-specific amplification that yielded fragments $>350 \mathrm{bp}$, while the second round used common primers to produce fragments that were $<350 \mathrm{bp}$, and therefore suitable for single strand conformation polymorphism (SSCP) analysis [21].

Amplifications were carried out in $10-\mu \mathrm{L}$ reactions containing $20 \mathrm{ng}$ of DNA template, $5 \mu \mathrm{L}$ of $2 \times \mathrm{GC}$ I buffer with $\mathrm{MgCl}_{2}$ (TaKaRa), $0.2 \mu \mathrm{mol} / \mathrm{L}$ of each primer, $0.2 \mathrm{mmol} / \mathrm{L}$ dNTP, and $0.25 \mathrm{U}$ Ex-Taq polymerase (TaKaRa). For the first-round PCR reaction, the following amplification conditions were used: $5 \mathrm{~min}$ at $95^{\circ} \mathrm{C}$ followed by $22-25$ cycles of $30 \mathrm{~s}$ at $95^{\circ} \mathrm{C}, 30 \mathrm{~s}$ at the annealing temperature (Table 2), and $1 \mathrm{~min}$ at $72^{\circ} \mathrm{C}$, with a final extension period of $5 \mathrm{~min}$ at $72^{\circ} \mathrm{C}$. The products of the first-round PCR were used as the templates for the second-round PCR, which started with 5 min of denaturation at $95^{\circ} \mathrm{C}$, followed by 30-35 cycles of $30 \mathrm{~s}$ at $95^{\circ} \mathrm{C}, 30 \mathrm{~s}$ at the annealing temperature, and $30 \mathrm{~s}$ at $72^{\circ} \mathrm{C}$, and ended with an elongation step at $72^{\circ} \mathrm{C}$ for $5 \mathrm{~min}$. Negative control reactions were amplified in each case to rule out possible contamination.

\subsection{MHC genotyping}

We used SSCP analysis to screen the PCR fragments, because this method is highly sensitive to variation and can detect differences of only a single base pair [27]. The obtained PCR products were mixed with equal volumes of gel loading buffer, denatured at $95^{\circ} \mathrm{C}$ for 3-4 min, chilled on ice, and then electrophoresed at $35 \mathrm{~W}$ on $12 \%$ nondenaturing polyacrylamide gels for $8-10 \mathrm{~h}$ at $4^{\circ} \mathrm{C}$. The resulting DNA bands were visualized by silver staining.

\subsection{Data analysis}

All sequences were edited and aligned using the DNASTAR software package (DNASTAR, Inc.). The antigen binding sites (ABS), identified by comparison to human sequences [28], were used to assess sequence variability.

Allele frequencies and deviations from Hardy-Weinberg equilibrium (HWE) for each locus were tested using exact tests, as implemented in GenePop 4.0 [29]. Observed $\left(H_{\mathrm{O}}\right)$ and expected $\left(H_{\mathrm{E}}\right)$ heterozygosities were calculated using

Table 2 Locus-specific primers used to amplify exons 2 and 3 from the Aime-MHC class I genes

\begin{tabular}{|c|c|c|c|c|}
\hline Locus & Primer name & Primer sequence $\left(5^{\prime} \rightarrow 3^{\prime}\right)$ & Size (bp) & $T_{\mathrm{a}}\left({ }^{\circ} \mathrm{C}\right)$ \\
\hline \multirow[t]{2}{*}{ Aime-CE2 } & $1611 \mathrm{E} 21 \mathrm{~F}^{\mathrm{a})}$ & GCTCTCCCCCACTCAGTA & 600 & 60.1 \\
\hline & $1611 \mathrm{E} 21 \mathrm{R}^{\mathrm{a})}$ & CAGCCGTACATCCACTGGTA & & \\
\hline \multirow[t]{2}{*}{ Aime-CE3 } & $1611 \mathrm{E} 34 \mathrm{~F}^{\mathrm{a})}$ & ATGACGTATTTCTACACCGGC & 1127 & 64.1 \\
\hline & $1611 \mathrm{E} 33 \mathrm{R}^{\mathrm{a})}$ & TGCAGGTCTAAGAGGGAGAGCGCT & & \\
\hline \multirow[t]{2}{*}{ Aime-FE2 } & $152 \mathrm{E} 2 \mathrm{~A} 3^{\mathrm{a}}$ & GCCCTGCTCTCCCCCACTCAG & 496 & 65.3 \\
\hline & $152 \mathrm{E} 2 \mathrm{~A} 4^{\mathrm{a})}$ & CGGGGGTTCCTGAGAGTTGGGGC & & \\
\hline \multirow[t]{2}{*}{ Aime-FE3 } & $152 \mathrm{E} 3 \mathrm{~A} 1^{\mathrm{a})}$ & AGTCCGAGCGTTGCCCCAACTCTC & 787 & 59.5 \\
\hline & $152 \mathrm{E} 3 \mathrm{~A} 2^{\mathrm{a})}$ & AGTAATGGCCCTGAGTAAGGTTTC & & \\
\hline \multirow[t]{2}{*}{ Aime-IE2 } & $128 \mathrm{E} 22 \mathrm{~F}^{\mathrm{a})}$ & CCTGCTCTCCCCAACGCG & 614 & 62.4 \\
\hline & $128 \mathrm{E} 22 \mathrm{R}^{\mathrm{a})}$ & GTCACAGCCGTGCATCCA & & \\
\hline \multirow[t]{2}{*}{ Aime-IE3 } & $128 \mathrm{E} 31 \mathrm{~F}^{\mathrm{a})}$ & CCGAGTGGACTTGCAGACCGCC & 1131 & 62.5 \\
\hline & $128 \mathrm{E} 32 \mathrm{R}^{\mathrm{a})}$ & GTCCGGGGTTTCTGAAGAAGAACG & & \\
\hline \multirow[t]{2}{*}{ Aime-LE2 } & $1300 \mathrm{E} 22 \mathrm{~F}^{\mathrm{a})}$ & GGGAGAAGGGTCGGGCGGGAC & 535 & 62.2 \\
\hline & $1300 \mathrm{E} 21 \mathrm{R}^{\mathrm{a})}$ & AGGTCACAGCCGTGCATCTC & & \\
\hline \multirow[t]{2}{*}{ Aime-LE3 } & $1300 \mathrm{E} 31 \mathrm{~F}^{\mathrm{a})}$ & GCTCTCACACCATCCAGGA & 887 & 62.1 \\
\hline & $1300 \mathrm{E} 31 \mathrm{R}^{\mathrm{a})}$ & GTCGGGGGTTTCTGAAGAAGAATC & & \\
\hline \multirow[t]{2}{*}{ Aime-C/F/I/LE2 } & $\mathrm{C} 1 \mathrm{E} 2 \mathrm{~B} 1^{\mathrm{b})}$ & TCAGCCCCTCCGCGCCCGCAG & 312 & 66.3 \\
\hline & $\mathrm{C} 1 \mathrm{E} 2 \mathrm{~B} 2^{\mathrm{b})}$ & GACCCGGGCCGCGTCGCTCAC & & \\
\hline \multirow[t]{2}{*}{ Aime-C/F/I/LE3 } & $\mathrm{C} 1 \mathrm{E} 3 \mathrm{~B} 1^{\mathrm{b})}$ & TCGCCTCCTGTCGGGCGGGGCCAG & 349 & 65.6 \\
\hline & $\mathrm{C} 1 \mathrm{E} 3 \mathrm{~B} 2^{\mathrm{b})}$ & AGCCAGCCCCAGCGGAGGGG & & \\
\hline
\end{tabular}

a) and b) indicate the first and second primer pairs used for the nested PCR, respectively. The same second-round primer pairs were used for all four classical loci. 
the program GENETIX4.05 [30].

\section{Results}

\subsection{Construction of MHC class I contigs and identification of Aime-MHC class I loci}

Using primer pairs $\mathrm{C} 1 \mathrm{E} 2 \mathrm{~F} 3 / \mathrm{R} 1$ and $\mathrm{C} 1 \mathrm{E} 3 \mathrm{~F} 1 / \mathrm{R} 1$, we isolated 16 positive BACs, 7 of which were used to form two contigs of minimum BAC tiling paths (Figure 1). GENESCAN predicted six MHC class I genes from these two contigs. Three were new and the remaining three corresponded to the previously reported Aime-128, -152 and -1906 loci [23]. For the purposes of this study, we designated the genes in the first contig as Aime-C, Aime-F, Aime-I, Aime-K and Aime-L (Figure 1(a)), and retained the name Aime-1906 for the single gene found in the second contig (Figure 1(b)). Aime-I, Aime-F, and Aime-1906 corresponded to Aime-128, -152 and -1906 loci respectively [18].

Analysis of the tissue expression patterns of these cDNAs showed that both Aime-K and Aime-1906 were expressed in brain and liver, but not in blood, whereas the other four genes were expressed in all three tested tissues (Figure 2). Furthermore, analysis of the full-length cDNA sequences for Aime-C, -F, -I, -K, -L and -1906 revealed that Aime-K lacked exon 7 and Aime-1906 had a prestop codon in exon 7, while the other four genes presented normal exonic structures (Figure 3). Therefore, we classified Aime-K and Aime-1906 as nonclassical genes and Aime-C, -F, -I and $-\mathrm{L}$ as classical loci. Accordingly, we used the latter four genes to establish locus-specific genotyping.

\subsection{Establishment of a locus-specific genotyping technique}

Genotyping of exons 2 (270 bp) and -3 (276 bp) from the four classical Aime-MHC class I loci was performed. We found that Aime-F was monomorphic, while Aime-C, -I and -L were polymorphic. No more than two sequences were present in any animal, indicating that our gene-specific primers did not produce cross-locus amplification. Furthermore, we obtained perfect genotype matches for all parent-offspring pairs, indicating that the utilized primers did not yield null alleles, and therefore represented the desired intra-locus conserved regions.

\subsection{Genetic variability of Aime-MHC class I genes}

In total, we obtained 4/4/4 exon 2 alleles and 6/5/5 exon 3 alleles from Aime-C/-I/-L, respectively (Table 3). All of the alleles were confirmed in either two individuals or two PCR reactions from the same individual. Consistent with our expression data (see above), none of the alleles contained any deletion, insertion or stop codon, suggesting that all of the detected sequences should represent functional molecules. Some of the alleles were highly frequent (e.g.,

(a)

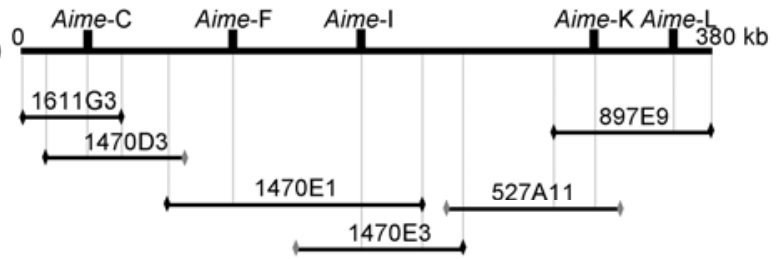

(b)

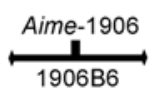

Figure 1 Two contigs representing the Aime-MHC class I region. The black and gray diamonds indicate the BAC ends used for primer design and repeats that were not used for primer design, respectively. The black rectangles represent the Aime-MHC class I genes.
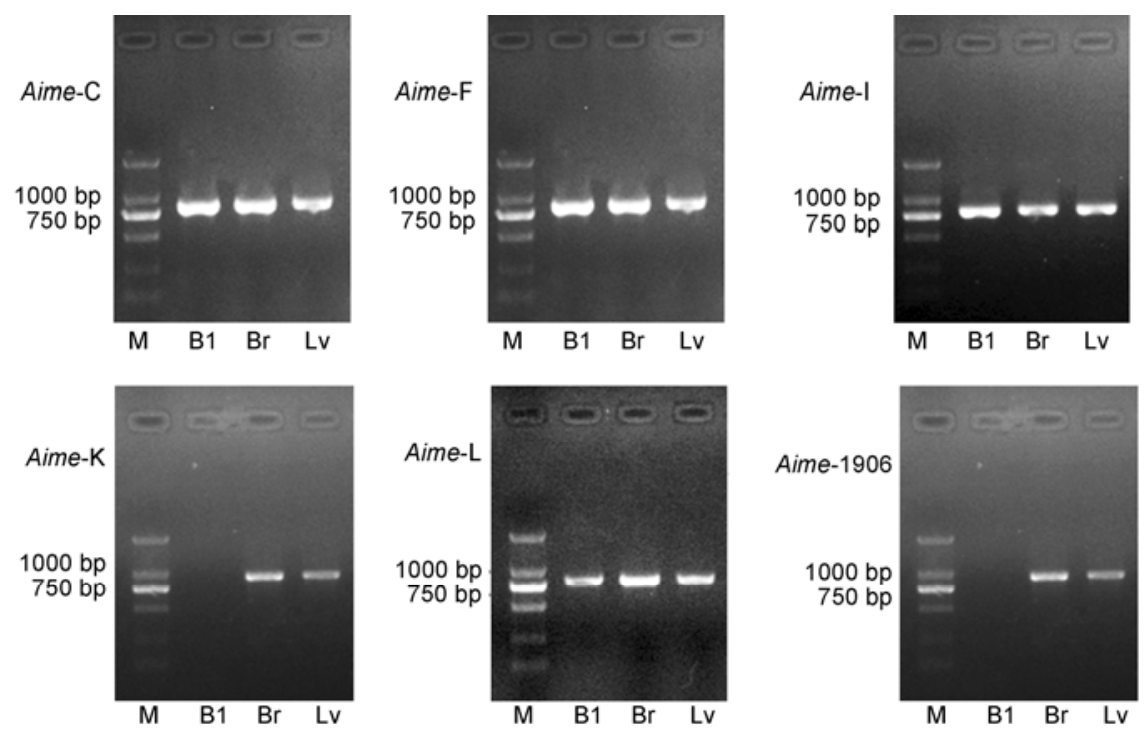

Figure 2 Expression levels of six Aime-MHC class I genes in different tissues. Bl, blood; Br, brain; and Lv, liver. 


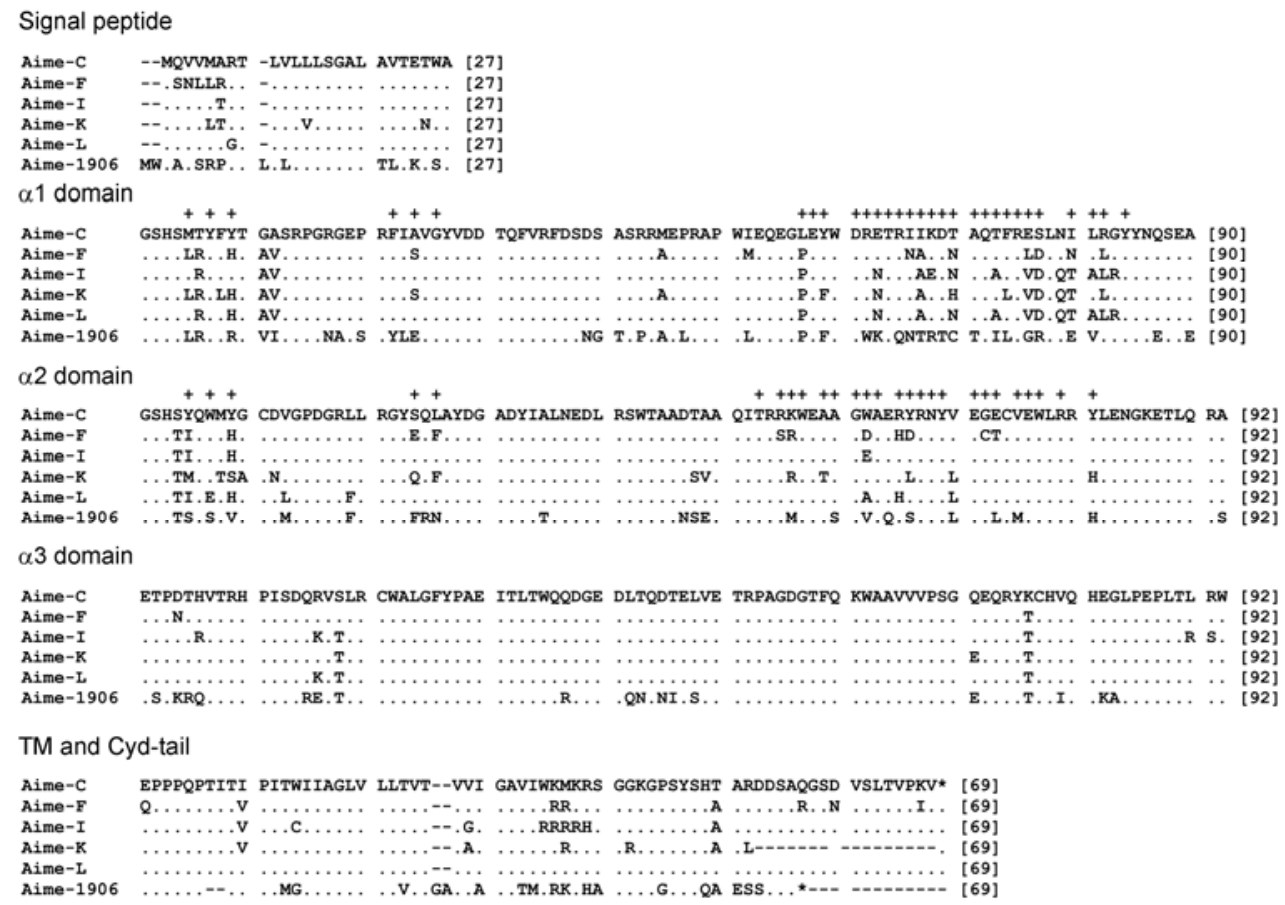

Figure 3 Amino acid alignments deduced from the Aime-MHC class I cDNA sequences. Dots and gaps indicate identities and missing amino acids, respectively, compared with the first sequence. Crosses represent putative peptide-binding sites, as determined using the method of Bjorkman et al. [28].

Table 3 Genotype frequencies and heterozygosities of the four classical MHC class I locia)

\begin{tabular}{|c|c|c|c|c|c|c|c|c|c|c|}
\hline & & $N_{\mathrm{a}}$ & 01 & 02 & 03 & 04 & 05 & 06 & $H_{\mathrm{O}}$ & $H_{\mathrm{E}}$ \\
\hline \multirow{4}{*}{ Exon 2} & Aime-C & 4 & 0.173 & 0.423 & 0.365 & 0.038 & - & - & 0.654 & 0.669 \\
\hline & Aime-F & 1 & 1.000 & - & - & - & - & - & - & - \\
\hline & Aime-I & 4 & 0.865 & 0.019 & 0.058 & 0.058 & - & - & 0.269 & 0.249 \\
\hline & Aime- $\mathrm{L}$ & 4 & 0.231 & 0.077 & 0.365 & 0.327 & - & - & 0.769 & 0.714 \\
\hline \multirow{4}{*}{ Exon 3} & Aime-C & 6 & 0.058 & 0.115 & 0.365 & 0.250 & 0.038 & 0.173 & $0.769 *$ & 0.771 \\
\hline & Aime- $\mathrm{F}$ & 1 & 1.000 & - & - & - & - & - & - & - \\
\hline & Aime-I & 5 & 0.019 & 0.750 & 0.096 & 0.058 & 0.077 & - & 0.308 & 0.427 \\
\hline & Aime- $\mathrm{L}$ & 5 & 0.077 & 0.019 & 0.231 & 0.327 & 0.346 & - & 0.769 & 0.728 \\
\hline
\end{tabular}

a) $N_{\mathrm{a}}$ is the number of alleles. The predominant allele is marked in bold. Asterisks denote significant deviations from $\mathrm{HWE}(P<0.05)$.

Aime-CE2*02, Aime-IE2*01, Aime-LE2*03 and 04, AimeCE $3 * 03$, Aime-IE3*02, and Aime-LE3*04 and 05), with two showing frequencies $>0.5$ (Aime-IE2*01 and Aime-IE3*02).

Similar levels of heterozygosities were observed at exon 2 (0.269-0.769) and exon 3 (0.308-0.769) for Aime-C/-I/-L. The HWE test showed no significant deviation for exons 2 and 3 at any locus with the exception of Aime-CE3. We found higher than expected heterozygosity at Aime-IE2, Aime-LE2 and Aime-LE3, and lower than expected heterozygosity at Aime-CE2, Aime-CE3 and Aime-IE3 (Table 3).

\subsection{Sequence variation among the Aime-MHC class I genes}

The alignment of exon 2 (270 bp) nucleotide sequences revealed 23/17/12 variable sites for Aime-C/-I/-L, respec- tively, corresponding to $14 / 10 / 18$ variable amino acids in the $\alpha 1$ domain. The alignment of exon 3 (276 bp) nucleotide sequences yielded 20/14/8 variable sites for Aime-C/$\mathrm{I} / \mathrm{L}$ respectively, corresponding to $9 / 7 / 10$ variable amino acids in the $\alpha 2$ domain (Figure 4 ). The mean number of variable amino acids in the $\alpha 1$ domains of the three polymorphic loci (14) was more than that in the $\alpha 2$ domains (8.7). Furthermore, the variable amino acids were concentrated in the ABS of both domains, suggesting that most of the variation was localized to the sites responsible for antigen recognition and presentation (Figure 4).

\section{Discussion}

The isolation of MHC class I genes can be complicated by 


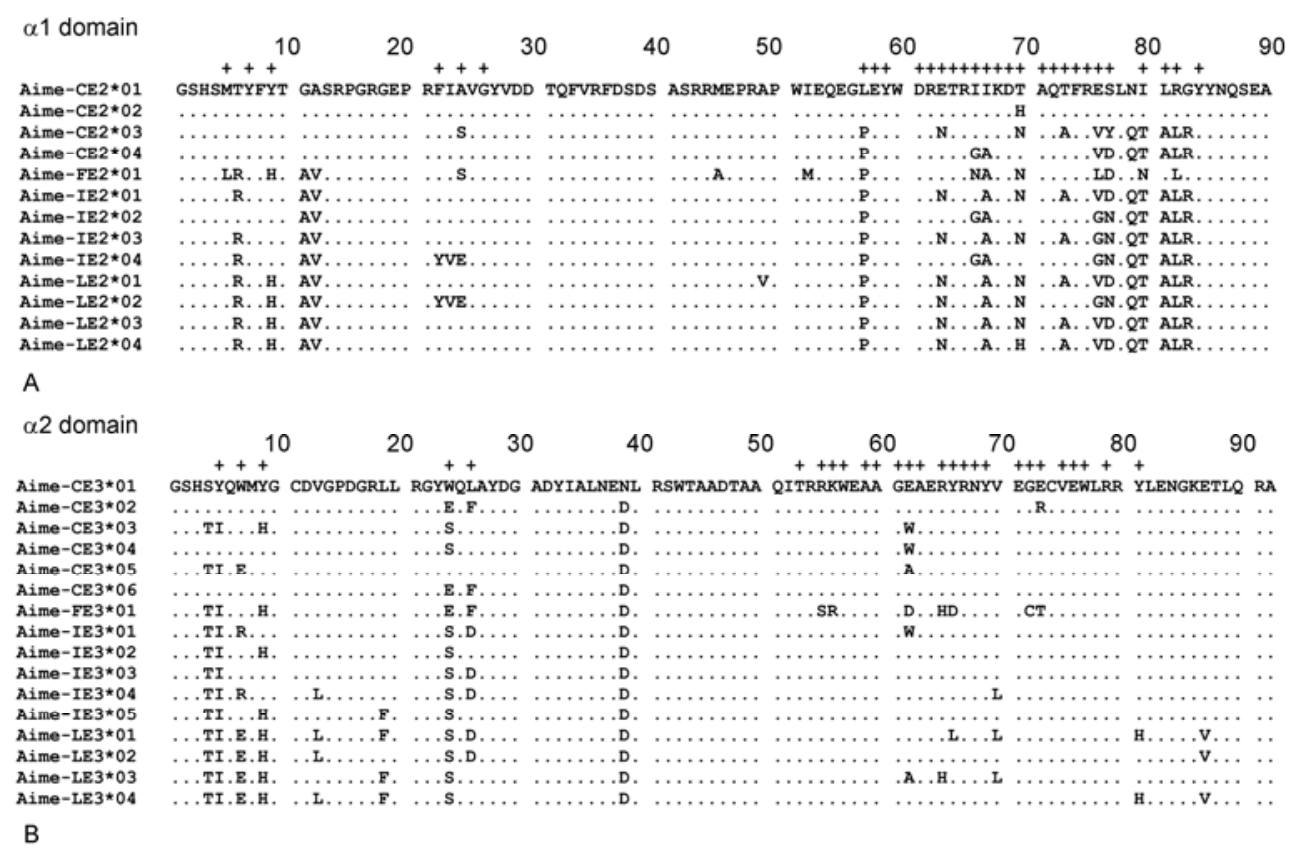

Figure 4 Amino acid alignments deduced from classical Aime-MHC class I alleles of the $\alpha 1$ (A) and $\alpha 2$ (B) domains. Dots and gaps indicate identities and missing amino acids, respectively, compared with the first sequence. Crosses represent putative peptide-binding sites, as determined using the method of Bjorkman et al. [28].

the high similarities among orthologous and paralogous members [31]; hence many studies on MHC variation have been conducted across multiple MHC class I genes [32,33]. However, such studies are unable to assign alleles to the individual loci, often making it impossible to identify true genotypes and recognize complex processes occurring at individual loci (e.g., selection pressure, mate behavior, and associations between MHC genotype and parasite load) $[13,34]$. Here, we successfully isolated six class I genes and developed a set of high-resolution genotyping primers for proper genotypic analysis of the giant panda. Using these primers, we found that the alleles previously identified for the so-called Aime-128 locus in Pan et al. [23] actually represented two loci: Aime-I and Aime-L. This also indicated that our locus-specific technique was effective.

In total, we identified 13 exon 2 alleles and 17 exon 3 alleles for the four classical Aime-MHC class I genes in 26 individuals, indicating that the giant panda retains a relatively high variability in its adaptive immune system. Sequence alignment reveals that the variable amino acids were mainly concentrated in the ABS positions (Figure 4), suggesting that polymorphism of Aime-MHC class I genes could be attributed to the requirement of antigen recognition and presentation.

In conclusion, we herein successfully isolated six functional MHC class I genes from the giant panda and established an effective locus-specific genotyping technique for the four classical MHC class I genes. This may provide a new viewpoint for isolating MHC genes for other species, and our data on genetic diversity may aid in captive breeding of the Chengdu population. Furthermore, our results provide a good reference for better understanding the giant panda's living situation and may facilitate the future establishment of detailed conservation strategies.

This work was supported by the National Basic Research Program of China (2007CB411600), the State Forestry Administration of China (WH0627), and the Fundamental Research Funds for the Central Universities of China.

1 Ebenhard T. Conservation breeding as a tool for saving animal species from extinction. Trends Ecol Evol, 1995, 10: 438-443

2 Seddon P J, Armstrong D P, Maloney R F. Developing the science of reintroduction biology. Conserv Biol, 2007, 21: 303-312

3 Frankham R. Genetic adaptation to captivity in species conservation programs. Mol Ecol, 2008, 17: 325-333

4 Robert A. Captive breeding genetics and reintroduction success. Biol Conserv, 2009, 142: 2915-2922

5 Chong A Y Y. Genetic variation in the MHC of the Collared peccary: A potential model for the effects of captive breeding on the MHC. Univ Sydney Undergr Res J, 2009, 1: 98-116

6 Sommer S. The importance of immune gene variability (MHC) in evolutionary ecology and conservation. Front Zool, 2005, 2: 1-18

7 Frankham R, Ballou J D, Briscoe D A. Introduction to Conservation Genetics. Cambridge: Cambridge University Press, 2002

8 Klein J. The Natural History of the Major Histocompatibility Complex. New York: Wiley \& Sons, 1986

9 Xu T J, Sun Y N, Chen S L. Allelic variation, balancing selection and positive selected sites detected from MHC class I a gene of olive flounder. Genetica, 2010, 138: 1251-1259

10 Bos D H, Waldman B. Evolution by recombination and transspecies polymorphism in the MHC class I gene of Xenopus laevis. Mol Biol Evol, 2006, 23: 137-143

11 Glaberman S, Du Pasquier L, Caccone A, et al. Characterization of a nonclassical class I MHC gene in a reptile, the galápagos marine iguana (Amblyrhynchus cristatus). PLoS One, 2008, 3: 1-11

12 Birch J, Codner G, Guzman E, et al. Genomic location and characterisation of nonclassical MHC class I genes in cattle. Immuno- 
genetics, 2008, 60: 267-273

13 Piertney S, Oliver M. The evolutionary ecology of the major histocompatibility complex. Heredity, 2006, 96: 7-21

14 Kassiotis G, Garcia S, Simpson E, et al. Impairment of immunological memory in the absence of MHC despite survival of memory $\mathrm{T}$ cells. Nat Immunol, 2002, 3: 244-250

15 Bernatchez L, Landry C. MHC studies in nonmodel vertebrates: What have we learned about natural selection in 15 years? J Evol Biol, 2003, 16: 363-377

16 Radwan J, Kawalko A, Wojcik J M, et al. MHC-DRB3 variation in a free-living population of the European bison, Bison bonasus. Mol Ecol, 2006, 16: 531-540

17 State Forestry Administration of China. The Third National Survey Report on Giant Panda in China (in Chinese). Beijing: Science Press, 2006

18 Xie Z, Gipps J. The 2012 International Studbook for Giant Panda (Ailuropoda melanoleuca). Beijing: Chinese Association of Zoological Garden, 2012

19 Wan Q H, Zeng C J, Ni X W, et al. Giant panda genomic data provide insight into the birth-and-death process of mammalian major histocompatibility complex class II genes. PLoS One, 2009, 4: e4147

20 Wan Q H, Zhu L, Wu H, et al. Major histocompatibility complex class II variation in the giant panda (Ailuropoda melanoleuca). Mol Ecol, 2006, 15: 2441-2450

21 Chen Y Y, Zhang Y Y, Zhang H M, et al. Natural selection coupled with intragenic recombination shapes diversity patterns in the major histocompatibility complex class II genes of the giant panda. J Exp Zool B (Mol Dev Evol), 2010, 314B: 208-223

22 Wan Q H, Zhang P, Ni X W, et al. A novel HURRAH protocol reveals high numbers of monomorphic MHC class II loci and two asymmetric multi-locus haplotypes in the Père David's Deer. PLoS One, 2011, 6: e14518

23 Pan H J, Wan Q H, Fang S G. Molecular characterization of major histocompatibility complex class I genes from the giant panda (Ailuropoda melanoleuca). Immunogenetics, 2008, 60: 185-193
24 Shen F J, Zhang Z H, He W, et al. Microsatellite variability reveals the necessity for genetic input from wild giant pandas (Ailuropoda melanoleuca) into the captive population. Mol Ecol, 2009, 18: 10611070

25 Sambrook J, Russell D W. Molecular Cloning: A Laboratory Manual, 3rd ed. Cold Spring Harbor. New York: Cold Spring Harbor Laboratory Press, 2001

26 Zeng C J, Pan H J, Gong S B, et al. Giant panda BAC library construction and assembly of a $650-\mathrm{kb}$ contig spanning major histocompatibility complex class II region. BMC Genomics, 2007, 8: $1-10$

27 Sunnucks P, Wilson A C C, Beheregaray L B, et al. SSCP is not so difficult: The application and utility of single-stranded conformation polymorphism in evolutionary biology and molecular ecology. Mol Ecol, 2000, 9: 1699-1710

28 Bjorkman P J, Saper M A, Samraoui B, et al. The foreigh antigen bing site and $\mathrm{T}$ cell recognition regions of class I histocompatibility antigens. Nat Immunol, 1987, 329: 512-518

29 Rousset F. GENEPOP'007: A complete re-implementation of the GENEPOP software for windows and linux. Mol Ecol Resour, 2008, 8: 103-106

30 Belkhir K, Borsa P, Chikhi L, et al. Genetix version 4.05, Logiciel sous windows TM pour la Génétique des populations, Montpellier: Université de Montpellier II, 2004

31 Kelley J, Walter L, Trowsdale J. Comparative genomics of major histocompatibility complexes. Immunogenetics, 2005, 56: 683-695

32 Kurtz J, Kalbe M, Aeschlimann P B, et al. Major histocompatibility complex diversity influences parasite resistance and innate immunity in sticklebacks. Proc R Soc B, 2004, 271: 197-204

33 Westerdahl H, Waldenstrom J, Hansson B, et al. Associations between malaria and MHC genes in a migratory songbird. Proc R Soc B, 2005, 272: 1511-1518

34 Spurgin L G, Richardson D S. How pathogens drive genetic diversity: MHC, mechanisms and misunderstandings. Proc R Soc B, 2010, 277: 979-988

Open Access This article is distributed under the terms of the Creative Commons Attribution License which permits any use, distribution, and reproduction in any medium, provided the original author(s) and source are credited. 